\title{
NIGHTTIME DISSOLVED OXYGEN DYNAMICS AND GROWTH PERFORMANCE OF NILE TILAPIA UNDER DIFFERENT FEED LOADS
}

(Received: 22.10.2011)

\author{
By \\ M.A. Elnady, R.K. Abd El Wahed and A.A. Abduljabbar \\ Animal Production Department, Faculty of Agriculture, Cairo University, Egypt
}

\begin{abstract}
Maximum feeding rate adopted in fish farming in still water in the western hemisphere ranges from $40-50 \mathrm{~kg}$ feed /ha /day (4-5 grams feed $/ \mathrm{m}^{2} /$ day) without water quality deterioration; while that of Egyptian water was not investigated. The study was conducted to assess the effect of feeding fish with constant areal (per area) feeding rates $\left(8,10,12,14 \mathrm{~g}\right.$ diet $/ \mathrm{m}^{2} /$ day) on daily oxygen production, nighttime community respiration and $\mathrm{pH}$ dynamics as well as the growth performance of Nile tilapia. The control treatment received a daily feeding rate load of $6.5 \mathrm{~g} / \mathrm{m}^{2} /$ day. The experiment lasted 90 days during summer season. Dusk oxygen concentrations in experimental tanks were significantly higher in the 8 gram and control treatments compared to those of 10,12 and 14 gram treatments .The 8 gram and control treatments had just the correct feeding rate $\left(6.5-8 \mathrm{~g} / \mathrm{m}^{2} /\right.$ day $)$ that exactly equaled the waste assimilative capacity of the water and sediment, resulting in a slightly positive oxygen budget at dawn. In the high feed loads $\left(10-14 \mathrm{~g} / \mathrm{m}^{2} /\right.$ day) treatments, the average nighttime community respiration exceeded the daytime net oxygen production, with duration of (near zero) depleted oxygen that ranged from 01:58 to 02: 55 hours before daybreak. All other treatments resulted in positive oxygen budgets, with oxygen surplus at dawn suggesting net autotrophy. The 8 grams and control treatments did not suffer oxygen deficiency before daybreak. Feed conversion ratios and daily weight gains were significantly improved in those treatments compared to the treatments with high feed loads. The better environment of the lower feeding rates improved treatment performance in terms of daily weight gain and feed conversion ratio.
\end{abstract}

Key words: feed load, maximum feeding rate, Nile tilapia, oxygen, $\mathrm{pH}$.

\section{INTRODUCTION}

Dissolved oxygen concentration is often considered to be the primary water quality factor limiting production intensification (Hargreaves, 2006). Generally, dissolved oxygen should be maintained for some warm water fish above $3 \mathrm{mg}$ /L. (Colt, 2006). Dissolved oxygen concentrations below this level will result in reduced growth and increased mortality (Colt et al., 2009). This is particularly true during the night, when there is no photosynthesis to produce oxygen. Consequently, monitoring oxygen levels is perhaps the single most critical management function (Boyd and Clay, 2002). Dissolved oxygen (DO) is widely considered to be the most limiting water quality variable affecting fish production. An adequate concentration of dissolved oxygen is needed to avoid stress and to assure good growth of the cultured species. Moreover, sufficient dissolved oxygen is needed in aquaculture systems to oxidize wastes and prevent them from accumulating to levels harmful to fish (Boyd, 2008). Two of the key parameters in ecosystem energy and mass flow are rates of gross primary production (GPP) and respiration (Howarth and Michaels, 2000).

Practical experience indicates that when artificial aeration is not used, critical point occurs when mid-summer, long-term feeding rates exceed 30 to 50 pound /acre per day (3-5 g feed $/ \mathrm{m}^{2} /$ day) (Tucker, 2003). As feeding rates increase past 30 to 50 pound/acre per day, a point is eventually reached where the capacity of the pond to assimilate and process fish waste products is exceeded, and fish growth rate decreases markedly due to the deterioration of water quality. Presumably, the waste assimilation capacity of the pond is exceeded when higher feeding rates are used because water quality deterioration suppresses fish appetite (Tucker, 2003). 
The sustainable operation of pond aquaculture is defined in large measure by the capacity of the pond to remove organic matter, a rate affected primarily by temperature and oxygen availability (Hargreaves and Tucker, 2003). Providing ponds with limited mechanical aeration (1-2 hp /acre) allows catfish farmers to feed up to about 100 $150 \mathrm{~kg}$ feed/ ha /day $\left(10-15 \mathrm{grams} / \mathrm{m}^{2} /\right.$ day, with normal fish growth and relatively few problems with acute water quality deterioration. If summertime feeding rates exceed those levels, especially for an extended time, feed consumption by fish decreases, presumably because the waste assimilation capacity of the pond is exceeded and water quality deterioration suppresses fish appetite (Hargreaves and Tucker, 2003).

The dry matter loading rate into a static culture system will directly influence the early morning dissolved oxygen concentration. Yakupitiyage, (1993) reported that the possible upper dry matter loading rate for a short duration (3-6 months ) for tilapia / carp polyculture system under artificial aeration was approximately $100 \mathrm{~kg}$ feed $\mathrm{DM} / \mathrm{ha}$ /day to maintain dissolved oxygen at approximately $1 \mathrm{mg}$ /litre at dawn.

Due to the high total pond oxygen demand resulting from high feeding rates, dissolvedoxygen concentration often falls below one part per million by morning, no matter when aeration is started. The primary goal of most managers is to keep the fish alive through the night and minimize visible stress as much as possible (Torrans, 2004).

Daily feed rations are generally related to the stocking density and size of fish. Feed rations typically increase with increased stocking density until high feed rates begin to result in deterioration of water quality (Losinger et al., 2000). Feed represents the largest single variable cost of fish production and an efficient use of feed can improve farm profitability. Also, operating feeding rate (as per area basis) within the assimilative capacity of the pond ecosystem will improve water quality inside the pond and provide a better environment for fish growth (Tucker, 2003). The objective of the current study was to evaluate the nighttime oxygen and $\mathrm{pH}$ dynamics and growth performance of Nile tilapia under different feed loads (feeding rates as per area basis) in semi-intensive system under Egyptian water quality conditions.

\section{MATERIALS AND METHODS}

The study was conducted at the Fish Research Unit, Faculty of Agriculture, Cairo University, Egypt during the summer of 2010. A static outdoor rearing system was used to carry out the experiment. Ten rectangular concrete tanks $\left(2.2^{*}\right.$ $1.2 * 1.0 \mathrm{~m}$ ) were filled with fresh water obtained from a well and were used as rearing units.

One month prior stocking, all tanks were fertilized with urea and superphosphate at a rate of 2.0 grams $\mathrm{N}$ and 0.5 gram $\mathrm{P}$ per square meter per week to enhance algal bloom. After stocking, all tanks were fertilized weekly at 1.0 gram N and $0.25 \mathrm{P}$ per square meter. Nile tilapia juveniles (132.8-158.6 grams/fish) were randomly distributed among the experimental tanks, with duplicate tanks per treatment. Each tank contained 7-10 tilapia juveniles.

\subsection{Experimental design}

The study was conducted to assess the effect of feeding fish with different levels of areal feeding rates $\left(8,10,12,14 \mathrm{~g}\right.$ diet $/ \mathrm{m}^{2} /$ day $)$ on algal photosynthesis, nighttime community respiration and $\mathrm{pH}$ dynamics as well as growth performance of Nile tilapia. Fish were fed with $25 \%$ crude protein under these areal feed loads in fertilized tanks. The control treatment received a daily feed load of $6.5 \mathrm{~g} / \mathrm{m}^{2} /$ day. The experiment lasted 90 days during summer season. The chemical fertilizer was applied weekly at the rate of 1.0 gram $\mathrm{N}$ and 0.25 gram phosphorus per square meter in each tank during the whole experiment.

\subsection{Oxygen and pH dynamics}

Calculations that predict nighttime decline in DO were based on Boyd et al. (1978) and Romaire and Boyd (1979). The projection method was used which is based on assuming that DO decline during nighttime is essentially linear with respect to time. An additional simplifying assumption was made, not to correct daytime net primary production (dNPP) or nighttime community respiration (nCR) for diffusion according to Hargreaves and Steeby (1999).

The $\mathrm{pH}$ changes during daytime and nighttime hours were considered as indices for community respiration in terms of the amount of $\mathrm{CO}_{2}$ consumed during daytime by algae or the amount of respiratory $\mathrm{CO}_{2}$ released during nighttime through community respiration. Consequently, the $\mathrm{pH}$ decline during nighttime reflected the rate of community respiration during nighttime while the 
$\mathrm{pH}$ increase during daytime reflected the daytime net rate of primary production (dNPP) by algae in terms of oxygen production.

Dissolved oxygen data were analyzed to calculate the duration that DO concentration was less than $1.0 \mathrm{mg} / \mathrm{L}$. in the per-dawn hours. Determination of daytime net primary production and nighttime community respiration required the measurements of dissolved oxygen. Water temperature was measured at dusk while DO and $\mathrm{pH}$ were measured three times daily (at early morning at 07: 00 a.m., dusk at 08:00 p.m. and nighttime at 00: 00 hour). The duration of nighttime hours during the last month of the experiment was approximately 10 hours while the daytime longevity lasted 14 hours.

\subsubsection{Oxygen dynamics parameters}

Nighttime community respiration per hour $\left(\mathrm{nRh}^{-1}\right)=($ dusk oxygen concentration - nighttime oxygen concentration) $/ 4$.

Nighttime community respiration $(\mathrm{nR})=$ hourly nighttime community respiration $* 10$.

Daytime net primary production $(\mathrm{dNPP})=$ dusk oxygen concentration - dawn oxygen concentration.

Dawn oxygen surplus or deficit $=\mathrm{dNPP}-\mathrm{nR}$.

Nighttime community respiration: daytime net primary production $(\mathrm{nR}: \mathrm{dNPP}$ ratio $)=\mathrm{nR} /$ dNPP.

Duration of oxygen supply above $1.0 \mathrm{~g} \mathrm{O}_{2} / \mathrm{m}^{2}=$ (dusk DO concentration -1) / $\mathrm{nRh}^{-1}$

Duration of oxygen supply above zero $\mathrm{g} \mathrm{O}_{2}$ $/ \mathrm{m}^{2}=$ dusk DO concentration $/ \mathrm{nRh}^{-1}$.

\subsection{2. pH dynamic parameters}

Daytime $\mathrm{pH}$ gain $(\mathrm{dpH}$ gain, units /daytime) $=$ dusk $\mathrm{pH}-$ early morning $\mathrm{pH}$.

Nighttime $\mathrm{pH}$ loss (npH loss, units / nighttime) $=$ dusk $\mathrm{pH}-$ next morning $\mathrm{pH}$.

Nighttime $\mathrm{pH}$ loss per nighttime hour ( $\mathrm{npH}$ loss $\mathrm{h}^{-1}$ ) $=$ nighttime $\mathrm{pH}$ loss $/ 10$.

Dawn $\mathrm{pH}$ surplus or deficit $=\mathrm{pH}$ gain $\mathrm{pH}$ loss.

Gross change of $\mathrm{pH}$ per day $=$ daytime $\mathrm{pH}$ gain + nighttime $\mathrm{pH}$ loss.

dNPP: $\mathrm{dpH}$ gain $=\mathrm{dNPP} / \mathrm{dpH}$ gain.

$\mathrm{nR}: \mathrm{npH}$ loss $=\mathrm{nR} / \mathrm{npH}$ loss.

\subsection{Growth performance}

Growth performance of the cultured fish was measured in terms of initial and final individual fish weight (gram) at the start and end of the experiment, daily weight gain (gram/fish /day) and feed conversion ratio (FCR).

\subsubsection{Daily weight gain (DWG)}

DWG = (final body weight -initial body weight)/ experimental period (days).

\subsubsection{Feed conversion ratio (FCR)}

Feed conversion ratio was determined as the grams of wet weight gain of fish per gram of dry diet consumed.

$\mathrm{FCR}=$ dry weight of feed fed $(\mathrm{g}) /$ weight gain of fish $(\mathrm{g})$.

\subsection{Water quality parameters}

Readings of temperature and dissolved oxygen were taken at dawn, dusk and next dawn by integrating the probe of the oxygen meter over the whole depth of water up to the bottom of the tank. Estimates of secchi disk visibility were made at the same time in each concrete tank. $\mathrm{pH}$ was measured by $\mathrm{pH}$ digital meter at the laboratory after sample collection. Total ammonia nitrogen was measured by the phenol method (APHA, 1992).

\subsection{Statistical analysis}

Growth performance of the cultured fish as well as water quality parameters in culture tanks were subjected to one -way analysis of variance to determine significant statistical differences among treatments. Differences among means were assessed by Duncan multiple range test (Duncan, 1955). Statistically significant differences were determined by setting type I error at $5 \%$ for each comparison.

\subsection{Oxygen dynamics \\ 3.1.1. Oxygen at dusk and daybreak}

Data of Oxygen dynamics in the experimental tanks are shown in Table (1). Dusk oxygen concentrations were significantly higher in the 8 gram and control treatments $(10.05-11.03 \mathrm{~g}$ $\mathrm{O}_{2} / \mathrm{m}^{2}$ ) compared to those of 10,12 and 14 gram treatments $\left(6.39-8.91 \mathrm{~g} \mathrm{O}_{2} / \mathrm{m}^{2}\right)$. The lower oxygen concentrations at dusk in the 10,12 and 14 gram treatments were due to the biological oxygen demand needed for feed metabolism and decomposition of feed wastes by aerobic bacteria during daytime hours. Better oxygen concentrations at dusk in the 8 grams and the control treatments were linked to the lower feed load (6.5 -8 g diet $/ \mathrm{m}^{2} /$ day) below the critical assimilation capacity of the water and sediment.

Feeding rates vary greatly among catfish producers, some producers feed to satiation, while others limit feed to a preset level because of concern about deteriorating water quality (Robinson and Li, 1999).

The general perception is that fish cannot be fed to satiation at the end of the growing season when biomass is high because the high level of feed input will deteriorate water quality to a point 
Table (1): Oxygen dynamics in fertilized concrete tanks under different feed loads (g feed/ $\mathrm{m}^{2} /$ day).

\begin{tabular}{|c|c|c|c|c|c|}
\hline \multirow{2}{*}{ Parameter } & \multicolumn{4}{|c|}{ Feed load } & \multirow{2}{*}{$\begin{array}{l}\text { Control } \\
6.5 \mathrm{~g} / \mathrm{m}^{2}\end{array}$} \\
\hline & $8 \mathrm{~g} / \mathrm{m}^{2}$ & $10 \mathrm{~g} / \mathrm{m}^{2}$ & $12 \mathrm{~g} / \mathrm{m}^{2}$ & $14 \mathrm{~g} / \mathrm{m}^{2}$ & \\
\hline Dusk oxygen concentration $\left(\mathrm{g} \mathrm{O}_{2} / \mathrm{m}^{2}\right)$ & $10.05^{\mathrm{ab}}$ & $6.39^{\mathrm{d}}$ & $7.62^{\mathrm{cd}}$ & $8.91^{\mathrm{bc}}$ & $11.03^{\mathrm{a}}$ \\
\hline Daybreak oxygen concentration $\left(\mathrm{g} \mathrm{O}_{2} / \mathrm{m}^{2}\right)$ & 1.63 & near zero & near zero & near zero & 0.78 \\
\hline $\begin{array}{l}\text { Nighttime respiration }\left(\mathrm{nCR}=\mathrm{g} \mathrm{O}_{2} /\right. \\
\left.\text { Nighttime } / \mathrm{m}^{2}\right)\end{array}$ & $8.42^{\mathrm{b}}$ & $9.10^{\mathrm{b}}$ & $9.70^{b}$ & $12.06^{\mathrm{a}}$ & $10.25^{\mathrm{ab}}$ \\
\hline Community respiration / hour $\left(\mathrm{g} \mathrm{O}_{2} / \mathrm{m}^{2} / \mathrm{hr}\right)$ & $0.84^{\mathrm{b}}$ & $0.91^{\mathrm{b}}$ & $0.97^{\mathrm{b}}$ & $1.20^{\mathrm{a}}$ & $1.02^{\mathrm{ab}}$ \\
\hline $\begin{array}{l}\text { Daytime net primary production }(\mathrm{dNPP})(\mathrm{g} \\
\mathrm{O}_{2} / \mathrm{m}^{2} / \text { daytime) }\end{array}$ & 8.42 & 6.39 & 7.61 & 8.91 & 10.25 \\
\hline $\begin{array}{l}\text { Duration of depleted oxygen before dawn } \\
\text { (hours) }\end{array}$ & none & $02: 55$ & $01: 58$ & 02:27 & none \\
\hline $\begin{array}{l}\text { Oxygen surplus/deficit }\left(\mathrm{g} \mathrm{O}_{2} / \mathrm{m}^{2}\right) \\
\text { at dawn }\end{array}$ & $1.63^{\mathrm{a}}$ & $-2.71^{b}$ & $-2.08^{b}$ & $-3.15^{b}$ & $0.78^{\mathrm{a}}$ \\
\hline nCR: dNPP ratio & 1.01 & 1.46 & 1.28 & 1.38 & 1.0 \\
\hline $\begin{array}{l}\text { Hours of } \mathrm{O}_{2} \text { supply above zero } \mathrm{g} \mathrm{O}_{2} \\
/ \mathrm{m}^{2} \text { (after dusk) }\end{array}$ & $12: 08^{\mathrm{a}}$ & $07: 04^{c}$ & $08: 01^{\mathrm{b}}$ & $07: 32^{\mathrm{c}}$ & $11: 43^{\mathrm{a}}$ \\
\hline $\begin{array}{l}\text { Hours of } \mathrm{O}_{2} \text { supply above } 1.0 \mathrm{~g} \mathrm{O}_{2} \\
/ \mathrm{m}^{2} \text { (after dusk) }\end{array}$ & $11: 12^{\mathrm{a}}$ & $06: 13^{b}$ & $07: 22^{b}$ & $06: 52^{b}$ & $10: 52^{\mathrm{a}}$ \\
\hline Water temperature $\left(\mathrm{C}^{0}\right)$ & $31.1^{\mathrm{ab}}$ & $30.5^{\mathrm{bc}}$ & $31.3^{\mathrm{a}}$ & $31.1^{\mathrm{ab}}$ & $31.6^{\mathrm{a}}$ \\
\hline Secchi disk $(\mathrm{cm})$ & $14.4^{\mathrm{ab}}$ & $11.3^{\mathrm{cd}}$ & $15.6^{\mathrm{ab}}$ & $17.0^{\mathrm{a}}$ & $15.3^{\mathrm{a}}$ \\
\hline Ammonia -nitrogen (mg/L.) & $0.56^{\mathrm{a}}$ & $0.61^{\mathrm{a}}$ & $0.60^{\mathrm{a}}$ & $0.56^{\mathrm{a}}$ & N.D. \\
\hline
\end{tabular}

that production may be reduced (Robinson and $\mathrm{Li}$, 1999).

Ghosh and Tiwari (2008) reported that the dusk DO concentration increased as the phytoplankton produced more oxygen through photosynthesis than was consumed through respiration and decay during daytime.

Excess areal feed loads can result in excessive feed oxygen demand since each gram of diet demands 1.3 grams of oxygen in the process of metabolic activities (Boyd, 2008). Excess feed loads always result in higher respiration rate of fish during active metabolism, increasing daytime oxygen demand.

Respiration resulting from bacterial decomposition of waste organic matter and fish respiration often exceeds gross photosynthesis (net heterotrophy) in aquatic systems with high rates of feed input, such as ponds used for waste water treatment or semi-intensive aquaculture (Hargreaves, 2006).

Ghosh and Tiwari (2008) reported that a healthy balance pond provides a fluctuation in oxygen levels between day and night that leaves an adequate concentration of oxygen in the water that can support aquatic animal life during night hours.

The decrease in DO at dusk in the high load treatments $\left(10,12\right.$ and $14 \mathrm{~g} / \mathrm{m}^{2} /$ day $)$ was due to the high feed oxygen demand during active metabolism of fish and the presence of excess feed load $\left(10-14 \mathrm{~g}\right.$ diet $/ \mathrm{m}^{2} /$ day $)$ above the 
waste assimilative capacity of the water and sediment.

Maximum DO concentration in earthen ponds is expected at dusk, while minimum DO concentration is expected at daybreak. In the present study, DO at daybreak ranged from near zero to $1.63 \mathrm{~g} \mathrm{O}_{2} / \mathrm{m}^{2}$ among treatments while DO at dusk ranged 6.39 to $11.03 \mathrm{~g} \mathrm{O}_{2} / \mathrm{m}^{2}$.The gap in DO concentrations between dusk and daybreak among those treatments ranged 7.61 to $10.35 \mathrm{~g}$ $\mathrm{O}_{2} / \mathrm{m}^{2}$ which indicated that these treatments are considered as hypereutrophic systems. Chang and Ouyang (1988) reported that the maximum change in DO concentration between day and night in a 24-h period was as great as $10 \mathrm{~g} \mathrm{O}_{2} / \mathrm{L}$.

\subsubsection{Daytime net primary production and} nighttime community respiration

Nighttime community respiration (nR) rates were estimated from a straight line interpolation over 4- hour period during the early nighttime period. High areal feed load (per area basis) always correlates with high feed oxygen demand due to the active metabolism of fish and the increased bacterial activities during the decomposition of faeces.

During the daylight hours, photosynthesis leads to an increase in the amount of oxygen, but after sunset the respiration and decomposition processes become dominant and draw on the oxygen content, so that its concentration decreases (Mukherjee et al., 2008).

Loss of oxygen from fish pond is always due to fish respiration, plankton respiration, water column respiration and sediment respiration (Ghosh and Tiwari, 2008). Photosynthesis supplies most of the oxygen to meet respiratory demand, although most of the oxygen produced in photosynthesis is consumed by phytoplankton respiration (Hargreaves and Tucker, 2003). Guocai et al. (2000) reported that the rate of plankton community respiration was nearly half $(49 \%)$ of the rate of phytoplankton gross production. Moreover, Teichert-Coddington and Green (1993) reported that water column respiration accounted for an average of 68\% (range: 53-76\%) of whole pond respiration (WPR) in two tropical fish ponds when water temperature was $>28{ }^{\circ} \mathrm{C}$.

Oxygen production by algal photosynthesis increases the oxygen content of water during daylight hours (dNPP) while the nighttime community respiration and decomposition by aerobic bacteria decreases oxygen content of water during nighttime hours (nR). In the high feed load $\left(10-14 \mathrm{~g} / \mathrm{m}^{2}\right)$ treatments, the average nighttime community respiration $(\mathrm{nR}=9.1-12.06$ $\mathrm{g} \mathrm{O}_{2} / \mathrm{m}^{2} /$ per nighttime) exceeded the daytime net primary production $\left(\mathrm{dNPP}=6.39-8.91 \mathrm{~g} \mathrm{O}_{2} / \mathrm{m}^{2}\right.$ per daytime) by a factor of about 1.28- 1.46:1, suggesting net heterotrophy, with a duration of (near zero) depleted oxygen that ranged from 01:58 to 02: 55 hours before daybreak. All other treatments resulted in positive oxygen budgets with a very low oxygen surplus $(0.78-1.63 \mathrm{~g}$ $\mathrm{O}_{2} / \mathrm{m}^{2}$ at daybreak), suggesting net autotrophy.

The balance between community respiration rate ( $\mathrm{nR}=$ water column and sediment respiration) during nighttime hours and the average daytime net primary production (dNPP) was used to determine the duration of DO concentration less than $1.0 \mathrm{mg} / \mathrm{L}$. in all treatments. According to Boyd (1990), algae produce most of oxygen by photosynthesis and consume most of oxygen by phytoplankton respiration. Nighttime community respiration ranged $0.84-1.02 \mathrm{~g} \mathrm{O}_{2} / \mathrm{m}^{2}$ /hour among treatments, except for the 14 gram treatment which had a higher nighttime community respiration $\left(\mathrm{nR}=1.2 \mathrm{~g} \mathrm{O}_{2} / \mathrm{m}^{2}\right.$ /hour) due to its high feed load ( $14 \mathrm{~g}$ diet $/ \mathrm{m}^{2} /$ day $)$.

Hargreaves and Steeby (1999) reported that the average ( minimum and maximum) net primary productivity and whole pond respiration rate $(\mathrm{mg}$ $/ \mathrm{L} . / \mathrm{h}$ ) of three commercial catfish ponds located in northwest Mississippi during the growing season in mid-summer ranged between (0.846-1.195 and $1.438-1.887 \mathrm{mg} / \mathrm{L} . / \mathrm{h})$ and $(0.668-0.956$ and 1.364 $-1.958 \mathrm{mg} / \mathrm{L} . / \mathrm{h})$, respectively.

In the 8 grams and control treatments, the average daytime net oxygen production (dNPP the $=8.42-10.25 \mathrm{~g} \mathrm{O} \mathrm{O}_{2} / \mathrm{m}^{2} /$ daytime) equaled the nighttime community respiration $(\mathrm{nR}=8.42-10.25$ $\mathrm{g} \mathrm{O}_{2} / \mathrm{m}^{2} /$ nighttime), which suggested slight net autotrophy conditions with surplus oxygen at daybreak. In this case, feed and fertilizer loadings were just equal to the waste assimilative capacity of water and sediment in terms of oxygen production $\left(\mathrm{g} \mathrm{O}_{2} / \mathrm{m}^{2} /\right.$ day).This oxygen production was needed to oxidize all organic matter inputs (i.e., dead algae and feed) during the process of bacterial and fish metabolism. In the high feed load treatments, the extra load (2-6 g diet $/ \mathrm{m}^{2} /$ day $)$ above the correct maximum feed load (8 $\mathrm{g} / \mathrm{m}^{2} /$ day) resulted in oxygen deficits before daybreak, suggesting that the feeding rate at 8 $\mathrm{g} / \mathrm{m}^{2} /$ day was the maximum feed load limit that just equaled the assimilative capacity of water in terms of oxygen availability needed for the oxidative metabolism. Above this areal feed load ( $8 \mathrm{~g}$ diet $/ \mathrm{m}^{2} /$ day), water would deteriorate to anoxic conditions in the pre -dawn hours.

\subsubsection{Oxygen budget at dawn}


Dawn oxygen surpluses were observed in the 8 gram and control treatments (1.63, and $0.78 \mathrm{~g}$ $\mathrm{O}_{2} / \mathrm{m}^{2}$, respectively), indicating net autotrophy and surplus oxygen concentrations at daybreak. However, dawn oxygen deficits were observed in the high feed load $\left(10-14 \mathrm{~g} / \mathrm{m}^{2}\right)$ treatments $(-2.08$ to-3.15 $\mathrm{g} \mathrm{O}_{2} / \mathrm{m}^{2}$ ), indicating net heterotrophy and near zero oxygen concentration in the per-dawn hours.

Excess feeding can result in the increase in organic matter, and the decrease in DO due to oxidation by bacteria and the increase in metabolic wastes (Boyd, 1990 and Millamena, 1990). Morning DO concentrations were also lower $(\mathrm{P}<$ 0.05) in pools receiving the higher feeding rate compared with the pools receiving the lower feeding rate (Allan et al., 1995).

Comparing nighttime oxygen budgets among treatments, it was apparent that dawn oxygen had surplus concentrations in the control and 8 gram treatments during the experimental period. These feed loads $\left(6.5-8 \mathrm{~g} / \mathrm{m}^{2}\right)$ were approximately the maximum feed load limits beyond which a negative oxygen budget would result and water quality would deteriorate in terms of metabolic activities. Adding an additional feed loads (2- $6 \mathrm{~g}$ diet $/ \mathrm{m}^{2} /$ day) in the high feed load treatments above this maximum daily areal feeding rate, resulted in negative dawn oxygen budgets $(-2.08$ to $-3.15 \mathrm{~g} \mathrm{O}_{2} / \mathrm{m}^{2}$ ). In this case, water during the pre-dawn hours were be aerated with oxygen through diffusion due to wind action at the airwater interface for several hours, with minute amount of oxygen available for fish survival.

In a typical 15-acre catfish pond, the total oxygen consumed in respiration by fish, plankton and sediment during summer may range from 45 to more than 90 kilograms of oxygen per hour (Tucker, 2005). Most of this oxygen demand was accounted for by plankton and sediment respiration rather than by fish.

When growth performance of Nile tilapia was compared with oxygen budget at dawn, it was concluded that the loading limit of organic matter as feed should not exceed $6.5 \mathrm{~g}$ dry matter $/ \mathrm{m}^{2}$ /day in order to reach better fish growth with a steady-state sustainable positive oxygen budget at dawn, without exceeding the waste assimilation capacity of static water.

\subsubsection{Dense algal bloom and oxygen budget}

Excessive algal bloom and high dead algae load at the bottom sediment affect the waste assimilative capacity of static water since most of the oxygen content in static water is consumed by phytoplankton respiration (Hargreaves and Tucker, 2003).

Slight differences in terms of secchi disk readings or excessive algal blooms were observed among the different feed load treatments. All treatments had excessive algal bloom (secchi disc $=11.3-17.0 \mathrm{~cm}$ ). The immediate expression of oxygen consumption from feeding is likely associated with fish respiration, which constitutes a minor (approximately $25 \%$ of total) component of whole pond respiration (Hargreaves and Steeby, 1999). In the longer term, the release of nutrients by fish excretion and organic matter mineralization stimulates the development of dense phytoplankton populations that constitute the major component of pond respiration (Hargreaves and Steeby, 1999).

\subsubsection{Nighttime respiration to daytime oxygen production}

Large nCR: dNPP ratios (total community respiration at night: daytime net primary (oxygen) production) were observed in the high feed load treatments $(1.28-1.46: 1)$ during nighttime which indicated that dissolved oxygen was depleted in the per -dawn hours. Guo-cai et al. (2000) indicated that large community respiration to gross oxygen production (CR: GPP) ratios (more than one) leads to depletion of dissolved oxygen before dawn, while small CR: GPP ratio (less than 1) indicates surplus oxygen at dawn. Yan and $\mathrm{He}$ (1997) reported that the ratio of CR: GPP is usually bigger than 1.0 in the high production fish ponds in China because higher amounts of manure and artificial feed are applied compared to the waste assimilative capacity of the ponds in terms of daily oxygen production. Moreover, too large a ratio of CR/GPP leads to depletion of dissolved oxygen in the per-dawn hours, while too small a ratio leads to weak decomposing process and low speed of material cycling (Yan and He, 1997).

In catfish ponds, most of the oxygen is produced by phytoplankton photosynthesis $(76.9 \%)$, and it is consumed by their own respiration $(57.5 \%)$. A smaller portion of the dissolved oxygen (DO) is demanded by fish $(22.5 \%)$ and sediment (19.4\%) respiration (Santa and Vinatea, 2007). Boyd (1990, 1998) reported that about $20 \%$ of dissolved oxygen in water was used by cultured species, while the remaining amount was consumed in respiration by 
phytoplankton, bacteria and benthic microorganisms. He recommended aeration during night hours to be good enough to ensure smooth growth process in intensive aquaculture.

The nighttime community respiration (nCR) to daytime net primary (oxygen) production ratio (nCR: dNPP) ranged 1.0-1.46:1 among treatments. The nCR: dNPP ratios in the 8 gram and control treatments indicated slight net autotrophy at dawn, while those of the high feed load treatments $\left(\begin{array}{lll}1.28 & -1.46 & : 1\end{array}\right)$ indicated net heterotrophy, with dissolved oxygen depletion (near zero concentrations) in the pre-dawn hours.

\subsubsection{The duration of depleted oxygen}

In the current study, constant community respiration $\left(\mathrm{g} \mathrm{O}_{2} / \mathrm{m}^{2} / \mathrm{hr}\right)$ during nighttime hours was assumed for the estimation of the duration that DO concentration was above $1.0 \mathrm{mg} / \mathrm{L}$ in the pre-dawn hours, according to Boyd et al. (1978) and Steeby et al. (2004). The value of DO above $1.0 \mathrm{mg} / \mathrm{L}$. was assumed since tilapia can withstand this concentration, without adverse effects on growth performance.

The duration of dissolved oxygen below certain threshold values provides an indication of the intensity of a low DO event (Hargreaves and Steeby, 1999). The duration of DO concentration less than $1.0 \mathrm{~g} \mathrm{O}_{2} / \mathrm{m}^{2}$ before daybreak differed significantly $(\mathrm{p}<0.05)$ among the treatments. The duration of DO less than $1.0 \mathrm{~g} \mathrm{O}_{2} / \mathrm{m}^{2}$ before daybreak was significantly maximum in the high feed load treatments (02:78 to 03:77 hours). Oxygen concentration had positive values at dawn in the 8 gram and control treatments (1.63 and $0.78 \mathrm{~g} \mathrm{O}_{2} / \mathrm{m}^{2}$ respectively).

Boyd and Clay (2002) reported that high concentrations of dissolved oxygen promote aerobic decomposition of organic matter by bacteria, allow efficient and rapid conversion of ammonia nitrogen to nitrate through bacteria nitrification, and prevent low early-morning dissolved oxygen concentrations typical of phytoplankton-based culture systems.

Tilapias can survive at low levels of dissolved oxygen (DO) as they can utilize atmospheric oxygen. However, low DO levels at dawn have been associated with reduced growth. Some indications have been found that low DO $(<0.5$ $\mathrm{mg} / \mathrm{L}$. ), generally occurring at dawn in green water systems, has negative impacts on the seed quantity. Low dissolved oxygen causes stress which brings behavioral (e.g., gasping) and morphological (marked melanin pigment in the skin) changes in the fish and reduced feed intake (Bhujel, 2000).
The duration of DO concentration at near zero $\left(\mathrm{g} \mathrm{O}_{2} / \mathrm{m}^{2}\right)$ before daybreak was maximum for the high feed load treatments (01: 58 to 02:55 hours). The 8 gram and control treatments did not suffer oxygen deficiency below 0.78 g $\mathrm{O}_{2} / \mathrm{m}^{2}$ before daybreak.

Roberts and Howarth (2006) indicated that the increase in phytoplankton community biomass should result in a corresponding increase in the total amount of respiration, being carried out by phytoplankton community. This is consistent with the notion of bacteria utilizing excreted DOC from phytoplankton as a carbon source during Psaturated conditions.

The duration (number of hours) of oxygen supply above zero and $1.0 \mathrm{~g} \mathrm{O}_{2} / \mathrm{m}^{2}$ in the fertilized tanks after dusk time ranged 07:04 to 12:08 and 06:13 to 11:12 hours, among treatments, respectively, with significant differences among means. Considering a nighttime period of 10:00 hours during this study, the high feed load treatments above 8 gram $/ \mathrm{m}^{2} /$ day should be avoided when nighttime aeration is not provided in farming systems.

\section{2. pH dynamics}

\subsubsection{Morning and dusk $\mathrm{pH}$}

Data of $\mathrm{pH}$ dynamics parameters are shown in Table (2). Lower averages of morning and dusk $\mathrm{pH}(\mathrm{p}<0.05)$ were observed in the high feed load treatments compared with the low feed load treatments. This probably followed the oxidative metabolism $\left(\mathrm{CO}_{2}\right.$ production) of the high feed load as well as the excessive algal respiration in the water column. Mukherjee et al. (2002) indicated that processes which utilize carbon dioxide (i.e., photosynthesis ) increase the $\mathrm{pH}$ while processes that release carbon dioxide( i.e., respiration) decrease the $\mathrm{pH}$.These two processes (photosynthesis and respiration ) change the carbon budget .

The extra carbon dioxide released during the pre-dawn hours under near zero oxygen concentration must have originated from the anaerobic $\mathrm{CO}_{2}$ production through the metabolic activities of anaerobic bacteria working on methane production, sulfate reduction or nitrate respiration. The resulting $\mathrm{CO}_{2}$ production would lower the $\mathrm{pH}$ values in water, although water had near zero oxygen concentration (Boyd, 1990).

\subsection{2. $\mathrm{pH}$ gains and losses}

During the day, photosynthesis has a significant impact on $\mathrm{pH}$. This is due to the consumption of carbon dioxide needed to produce oxygen (Colt et al., 2009). The control treatment had dawn $\mathrm{pH}$ surplus (+0.104) with higher 
Table (2): pH dynamics in fertilized concrete tanks under different feed loads (g feed $/ \mathrm{m}^{2} /$ day).

\begin{tabular}{|c|c|c|c|c|c|}
\hline \multirow{2}{*}{ Parameter } & \multicolumn{4}{|c|}{ Feed load } & \multirow{2}{*}{$\begin{array}{l}\text { Control } \\
6.5 \mathrm{~g} / \mathrm{m}^{2}\end{array}$} \\
\hline & $8 \mathrm{~g} / \mathrm{m}^{2}$ & $10 \mathrm{~g} / \mathrm{m}^{2}$ & $12 \mathrm{~g} / \mathrm{m}^{2}$ & $14 \mathrm{~g} / \mathrm{m}^{2}$ & \\
\hline Morning $\mathrm{pH}$ (units) & $8.30^{\mathrm{b}}$ & $7.89^{\mathrm{d}}$ & $8.12^{\mathrm{bc}}$ & $8.02^{\mathrm{cd}}$ & $8.92^{\mathrm{a}}$ \\
\hline Dusk pH (units) & $8.98^{b}$ & $8.45^{\mathrm{c}}$ & $8.80^{b}$ & $8.86^{b}$ & $9.568^{\mathrm{a}}$ \\
\hline $\mathrm{pH}$ gain (unit/ daytime) & $0.681^{\mathrm{bc}}$ & $0.553^{\mathrm{c}}$ & $0.687^{\mathrm{bc}}$ & $0.839^{\mathrm{ab}}$ & $0.64^{\mathrm{bc}}$ \\
\hline Midnight pH (units) & $8.69^{b}$ & $8.10^{c}$ & $8.43^{b}$ & $8.44^{b}$ & $9.35^{\mathrm{a}}$ \\
\hline $\begin{array}{l}\mathrm{pH} \text { loss/nighttime hour } \\
\text { (unit/Ngt/hr) }\end{array}$ & $0.072^{\mathrm{bc}}$ & $0.085^{\mathrm{ab}}$ & $0.093^{\mathrm{ab}}$ & $0.105^{\mathrm{a}}$ & $0.054^{\mathrm{c}}$ \\
\hline $\begin{array}{l}\text { Nighttime } \mathrm{pH} \text { loss (unit/ nighttime } \\
\text { period) }\end{array}$ & $0.72^{\mathrm{bc}}$ & $0.858^{\mathrm{ab}}$ & $0.933^{\mathrm{ab}}$ & $1.05^{\mathrm{a}}$ & $0.544^{\mathrm{c}}$ \\
\hline $\mathrm{pH}$ surplus /deficit $\quad( \pm$ unit $)$ & $-0.039^{a b}$ & $-0.305^{c}$ & $-0.245^{\mathrm{bc}}$ & $-0.215^{\mathrm{bc}}$ & $0.104^{\mathrm{a}}$ \\
\hline Gross change of $\mathrm{pH}$ per day & $1.73^{\mathrm{bc}}$ & $2.06^{\mathrm{ab}}$ & $2.24^{\mathrm{ab}}$ & $2.53^{\mathrm{a}}$ & $1.30^{\mathrm{d}}$ \\
\hline Dissolved oxygen gain/pH gain & 16.75 & 17.69 & 12.59 & 13.77 & 17.68 \\
\hline Dissolved oxygen loss/pH loss & 12.18 & 11.86 & 11.07 & 11.93 & 16.46 \\
\hline
\end{tabular}

Means in the same row with different letters are significantly different $(\mathrm{P}<0.05)$.

Table (3): Growth and feed performances in fertilized concrete tanks under different feed loads ( $\mathrm{g}$ feed $/ \mathrm{m}^{2} /$ day).

\begin{tabular}{|l|c|c|c|c|c|}
\hline \multirow{2}{*}{ Treatment } & \multicolumn{4}{|c|}{ Feed load } & Control \\
\cline { 2 - 6 } Parameter & $8 \mathrm{~g} / \mathrm{m}^{2}$ & $10 \mathrm{~g} / \mathrm{m}^{2}$ & $12 \mathrm{~g} / \mathrm{m}^{2}$ & $14 \mathrm{~g} / \mathrm{m}^{2}$ & $6.5 \mathrm{~g} / \mathrm{m}^{2}$ \\
\hline $\begin{array}{l}\text { Initial weight (grams } \\
\text { /fish ) }\end{array}$ & $150.0^{\mathrm{a}}$ & $134.2^{\mathrm{b}}$ & $158.6^{\mathrm{a}}$ & $154.4^{\mathrm{a}}$ & $132.88^{\mathrm{a}}$ \\
\hline $\begin{array}{l}\text { Final weight (grams } \\
\text { /fish ) }\end{array}$ & $206.0^{\mathrm{a}}$ & $168.4^{\mathrm{b}}$ & $198.9^{\mathrm{a}}$ & $201.1^{\mathrm{a}}$ & $207.4^{\mathrm{ab}}$ \\
\hline $\begin{array}{l}\text { Daily weight } \\
\text { gain(g/fish/d) }\end{array}$ & $0.66^{\mathrm{a}}$ & $0.34^{\mathrm{c}}$ & $0.44^{\mathrm{bc}}$ & $0.52^{\mathrm{b}}$ & $0.82^{\mathrm{ab}}$ \\
\hline $\begin{array}{l}\text { Feed conversion ratio } \\
\text { (FCR) }\end{array}$ & $3.32^{\mathrm{b}}$ & $5.34^{\mathrm{a}}$ & $6.35^{\mathrm{a}}$ & $6.54^{\mathrm{a}}$ & $2.46^{\mathrm{b}}$ \\
\hline
\end{tabular}

Means in the same row with different letters are significantly different $(\mathrm{P}<0.05)$.

daytime $\mathrm{pH}$ gain $(+0.64)$ than nighttime $\mathrm{pH}$ loss ($0.54)$. This indicated that more carbon dioxide was fixed by photosynthesis during daytime than was released during nighttime respiration. Therefore, more oxygen was produced by photosynthesis during daytime than was consumed by nighttime respiration, indicating oxygen surpluses at dawn.
The carbon cycle in experimental tanks was reflected in the magnitude of gross $\mathrm{pH}$ change per day in water during the experiment. The averages of gross $\mathrm{pH}$ change in water per day ranged 1.3 to 2.53 units /day among treatments, with significant differences among means $(\mathrm{P}<0.05)$. The gross $\mathrm{pH}$ change reflects the biological activities of aquatic 
organisms in terms of respiration and photosynthesis. Higher values of $\mathrm{pH}$ change reflect higher biological activities in water.

In the high feed load treatments (10 to $14 \mathrm{~g}$ $\operatorname{diet} / \mathrm{m}^{2} /$ day), the decomposition of feed wastes and faeces in the anaerobic bottom sediments, added respiratory $\mathrm{CO}_{2}$ through the anaerobic bacterial respiration using sulfate $\left(\mathrm{SO}_{4}\right)$ and nitrate $\left(\mathrm{NO}_{3}\right)$ respiration or through methane production which lowered the $\mathrm{pH}$ value in the pre-dawn hours. Dense growth of algae found in all treatments is considered as a major input of decomposable organic matter when settled at the bottom sediment.

In green water systems, carbon dioxide is added through community respiration and is removed through photosynthesis. Oxygen consumption by bacteria during the process of decomposition of feed wastes and dead phytoplankton often exceeds gross photosynthesis (net heterotrophy ) in aquatic systems with high rates of allochtonous organic matter such as feed (Hargreaves, 2006). This leads to near zero oxygen concentrations for several hours before dawn in ponds with high algal density where a large proportion of the water column (dark zone) is considered a net consumer of oxygen (Hargreaves, 2006).

The nutrients derived from the organic wastes and unused feed, enhance algal growth. Dense growths of algae contribute large amounts of DO in ponds during the daylight period, resulting in super-saturation of oxygen in the epilimnion, but consume substantial quantities of oxygen at night causing anoxic conditions in pre-dawn hours (Boyd, 1982; Chang and Ouyang, 1988).

Mukherjee et al. (2008) indicated that the change in the total inorganic carbon (total $\mathrm{CO}_{2}$ ) due to photosynthesis, respiration and decomposition could be quantified by measuring the $\mathrm{pH}$. Leiher et al. (1988) indicated that the minimum oxygen concentration at dawn can be reached when the rate of carbon dioxide consumption by algae during daytime is exactly balanced by its rate of production due to respiration (cited in Mukherjee et al., 2008).The addition or removal of carbon dioxide changes the $\mathrm{pH}$ value through community respiration and photosynthesis, respectively.

Phytoplankton as a major oxygen consumer during nighttime produce high amount of $\mathrm{CO}_{2}$ during dark period, thus lowering $\mathrm{pH}$ value during nighttime. Pawar et al. (2009) indicated that phytoplankton are the primary in situ oxygen production component during daylight and the major variable oxygen consumer during nighttime, thus increasing the range of diel water quality (i.e., dissolved oxygen and $\mathrm{pH}$ ) with the progress of the culture period.

In the current experiment, the $\mathrm{pH}$ was depressed during nighttime hours due to the excretion of respiratory $\mathrm{CO}_{2}$. The $\mathrm{pH}$ loss during nighttime ranged from -0.54 units to -1.05 units among treatments $(\mathrm{P}<0.05)$.

\subsubsection{Dawn pH surpluses /deficits}

Evaluation of the daily trends in $\mathrm{pH}$ values indicated that the feed load treatments $(10$ to $14 \mathrm{~g}$ diet $/ \mathrm{m}^{2} /$ day) were characterized by net heterotrophy. The dawn $\mathrm{pH}$ surplus / deficit parameter had negative values (- 0.215 to -0.305$)$ in those treatments, indicating that more carbon dioxide was released during nighttime respiration than was fixed by photosynthesis during daytime. This was indicated by the higher values of nighttime $\mathrm{pH}$ loss (- 0.85 to -1.05 unit) compared to those of the daytime $\mathrm{pH}$ gains $(+0.55$ to +0.83$)$ within each treatment.

High $\mathrm{pH}$ deficit values $(-0.21$ to -0.30$)$ were observed in the high feed load treatments indicating intense net heterotrophy. This could be explained by the presence of anaerobic conditions in the bottom sediments rich in feed wastes and dead algae. The production of the respiratory $\mathrm{CO}_{2}$ by the anaerobic bacteria working on feed wastes at the bottom sediment accounted for the higher nighttime $\mathrm{pH}$ loss in those treatments. It is known that the aerobic bacteria slow their decomposition activities when dissolved oxygen decrease below $2.0 \mathrm{mg} / \mathrm{L}$. The production of the respiratory $\mathrm{CO}_{2}$ by the anaerobic bacteria at the bottom sediment induced the higher $\mathrm{pH}$ deficit under limited oxygen budget.

Mukherjee et al. (2002) indicated that community respiration can be measured from the rate of $\mathrm{pH}$ loss during nighttime where there is no photosynthetic demand for carbon dioxide while the biota release carbon dioxide through community respiration. King and Novak (1974) and King (1970) reported that when the nighttime respiratory release of carbon dioxide by community respiration is equal to the daytime photosynthetic uptake of $\mathrm{CO}_{2}$, then the dawn surplus /deficit equal zero and the dawn $\mathrm{pH}$ value stay the same over time during the growing season (cited by Mukherjee et al., 2008).

Although visible signs of oxygen stress were never observed in the low oxygen treatment, feed consumption was reduced by $45 \%$, and average fish weight in the low oxygen treatment was $30 \%$ less than the control (Torrans, 2004). Moreover, 
net production was also cut in half in the experiment. This indicates why the high feed load treatments did not have good performance under negative oxygen budget. Tucker (2005) reported that depending on how low the dissolved oxygen concentration is and how long it remains low, fish may consume less feed, grow slowly, convert feed less efficiently, be more susceptible to infectious diseases.

\subsubsection{Oxygen to $\mathrm{pH}$ gain /loss ratio}

Averages of oxygen gain to $\mathrm{pH}$ gain ratio during daytime ranged 12.59 to $17.68: 1$ among treatments, while averages of oxygen loss to $\mathrm{pH}$ loss ratio during nighttime ranged 11.07 to 16.46 $: 1$ among treatments, with significant differences among means $(\mathrm{P}<0.05)$. Better oxygen production per one unit of $\mathrm{pH}$ change was observed in the 8 gram and control treatments (16.75-17.68:1) compared to those of the high feed load treatments (12.59-17.69:1), which reflected a better environment in those treatments.

\subsection{Growth performance}

Data of growth performance are shown in Table (3). The 8 gram and control treatments had higher dissolved oxygen content through the nighttime period, higher daytime net primary productivity and better environmental conditions for fish production. Feed conversion ratios (2.263.32: 1) and daily weight gains (0.66-0.83 $\mathrm{g} / \mathrm{fish}$ /day) were significantly improved in those treatments compared to the treatments with high feed loads. The better environment and assimilative capacity of water and sediment improved treatment performance in terms of daily weight gain of fish and feed conversion ratio. Hargreaves (2006) reported that if water quality tolerance limits of cultured fish are exceeded, especially for an extended time, feed consumption by fish decreases, presumably because the waste assimilation capacity of the pond is exceeded and water quality deterioration suppresses fish appetite.

In conclusion when growth performance of Nile tilapia was compared with oxygen budget at dawn, it was concluded that the loading limit of areal feeding rates should not exceed $6.5 \mathrm{~g}$ dry feed $/ \mathrm{m}^{2} /$ day in order to reach normal fish growth, with a steady - state sustainable positive oxygen budget at dawn without exceeding the waste assimilation capacity of static water. Considering a nighttime period of 10:00 hours during this study, the high feed load treatments above 8 gram
$/ \mathrm{m}^{2} /$ day should be avoided when nighttime aeration is not provided in farming systems.

\section{REFERENCES}

Allan G.L., Moriarty D.J.W and Maguire G.B. (1995). Effects of pond preparation and feeding rate on production of Penaeus monodon fabricus, water quality, bacteria and benthos in model farming ponds. Aquaculture, 130: 329-349.

APHA (1992). Standard Method of the Examination of Water and Waste Water. American Public Health Association, New York, pp.1193.

Bhujel R.C. (2000). A review of strategies for the management of Nile tilapia (Oreochromis niloticus) brood fish in seed production systems, especially hapa-based systems. Aquaculture, 181:37-59.

Boyd C.E. (1982). Water Quality Management for Pond Fish Culture. Elsevier, New York, NY, pp. 318.

Boyd C.E. (1990). Water Quality in Ponds for Aquaculture. Alabama Agricultural Experimental Station, Auburn University, Auburn, AL, pp. 482.

Boyd C.E. (1998). Mechanical aeration in pond aquaculture. Proceedings of FEDMS 98, Second International Symposium on Aeration Technology, June 21-25, 1998. Washington DC, pp. 1- 6 .

Boyd C.E. (2008). Calculating the feed oxygen demand (FOD) of aquafeeds. Kasetsart University Fisheries Research Bulletin, 32(3): 26-31.

Boyd C. E. and Clay, J.W. (2002). Evaluation of Belize Aquaculture Ltd.: A Super intensive Shrimp Aquaculture System. Report Prepared Under the World Bank, NACA, WWF and FAO Consortium Program on Shrimp Farming and the Environment. Published by the Consortium, pp. 17.

Boyd C.E., Romaire R.P. and Johnson E. (1978). Predicting early morning dissolved oxygen concentration in channel catfish ponds. Trans. Am. Fish. Soc., 107(3): 484- 492.

Chang W.Y. B. and Ouyang H. (1988). Dynamics of dissolved oxygen and vertical circulation in fish ponds. Aquaculture, 74: 263-276.

Colt J. (2006). Water quality requirements for reuse systems. Aquacultural Engineering, 34:143-156. 
Colt J., Watten B. and Rust M. (2009). Modeling carbon dioxide, $\mathrm{pH}$, and un-ionized ammonia relationships in serial reuse systems .Aquacultural Engineering, 40:2844.

Duncan D.B. (1955).Multiple range and Multiple F tests. Biometrics, Vol.11:1-42.

Ghosh L. and Tiwari G.N. (2008). Computer modeling of dissolved oxygen performance in greenhouse fish pond: An experimental validation. International Journal of Aquaculture Research, 3(2):83-97.

Guo-cai L., De-shan L. and Shuang-lin D. (2000). Carbon cycle in shrimp polyculture mesocosm. Chinese Journal of Oceanology and Limnology, 18(1): 67-73.

Hargreaves J.A. (2006). Photosynthetic suspended-growth systems in aquaculture. Aquacultural Engineering, 34: 344-363.

Hargreaves J.A. and Steeby J.A. (1999). Factors affecting metabolism of commercial channel catfish ponds as indicated by continuous dissolved oxygen measurement. Journal of the World Aquaculture Society, 30: 410-421.

Hargreaves J.A. and Tucker C.S. (2003). Defining loading limits of static ponds for catfish aquaculture. Aquacultural Engineering, 28:47-63.

Howarth R.W. and Michaels A.F. (2000). The measurement of primary production in aquatic ecosystems. In:O. Sala, R. Jackson, H. Mooney and R. Howarth (Eds.). Methods in Ecosystem Science. Springer, pp. 72-85.

King D.L. (1970). The role of carbon in eutrophication. J. Water Pollut. Control Fed., 42: 2035-2051.

King D.L. and Novak, J.D. (1974). The kinetics of inorganic carbon limited algal growth. J. Water Pollut. Control Fed., 46:1812-1816.

Leiher S.K., Eheart J.W. and Suidan M.T. (1988). A modelling study of the effect of $\mathrm{pH}$ on carbon limited algal biofilms. Water Research, 22:1033-1041.

Losinger W., Dasgupta S., Engle C. and Wagner B. (2000). Economic interaction between feeding rates and stocking densities in intensive catfish Ictalurus punctatus production. Journal of the World Aquaculture Society, 31 (4):491-502.

Millamena O. M. (1990). Organic pollution resulting from excess feed and metabolic build-up: Effect on penaeus monodon postlarvae. Aquacultural Engineering, 9: 143-150.

Mukherjee B., Pandey P.N. and Singh S.N. (2002). Mathematical modelling and system analysis of inorganic carbon in the aquatic environment. Ecological Modeling, 152:129-143.

Mukherjee B., Mukherjee D. and NiveditaM. (2008). Modelling carbon and nutrient cycling in a simulated pond system at Ranchi. Ecological Modeling, 213:437-448.

Pawar N.A., Jena J.K., Das P.C. and Bhatnagar D.D. (2009). Influence of duration of aeration on growth and survival of carp fingerlings during high density seed rearing. Aquaculture, 290: 263-268.

Roberts B.J. and Howarth R.W. (2006). Nutrient and light availability regulate the relative contribution of autotrophs and heterotrophs to respiration in freshwater pelagic ecosystems. Limnol. Oceanogr. , 51(1): 288-298.

Robinson E.H. and Li M.H. (1999). Effect of dietary protein concentration and feeding rate on weight gain, feed efficiency, and body composition of pond-raised channel catfish Ictulurus punctatus. Journal of the World Aquaculture Society, 30 (3):311318.

Romaire R.P. and Boyd C.E. (1979). Effects of solar radiation on the dynamics of dissolved oxygen in channel catfish ponds. Trans. Am. Fish. Soc., 108:473-480.

Santa K.D. and Vinatea L. (2007). Evaluation of respiration rates and mechanical aeration requirements in semi-intensive shrimp Litopenaeus vannamei culture ponds. Aquacultural Engineering, 36:73-80.

Smith D.W. and Piedrahita R.H. (1988). The relation between phytoplankton and dissolved oxygen in fish ponds. Aquaculture, 68:249-265.

Steeby J. A., Hargreaves J.A., Tucker C.S. and Kingsbury S. (2004). Accumulation, organic carbon and dry matter concentration of sediment in commercial channel catfish ponds. Aquacultural Engineering, 30: 115126.

Szyper J.P. (1996). Observation and model prediction of daily areal primary production in a atrophic brackish water culture pond. Ecological Modelling, 88:83-92.

Teichert-Coddington D. and Green B. (1993). Comparison of two techniques for 
determining community respiration in tropical fish ponds. Aquaculture, 114:41-50.

Torrans E. (2004). Optimum oxygen for catfish ponds. Doreen Muzzi Farm Press, pp. 2.

Tucker C. S. (2003). Best management practices for pond aquaculture. In:R.C. Summerfelt and R.D. Clayton (Eds.).Aquaculture effluents: overview of EPA guidelines and standards and BMPS for ponds, raceways, and recycle culture system. Proceedings from the conference, Ames, Iowa. Publication Office, North Central Regional Aquaculture Center, Iowa State University, Ames, Iowa, pp. 93-110.
Tucker C.S. (2005). Pond aeration. SRAC Publication, No. 3700, pp. 8.

Yakupitiyage A. (1993). On -farm feed preparation and feeding strategies for carps and tilapias. In: M.B .New, A.G.J. Tacon and 1.Csavas (Eds.). Farm- made Aquafeeds. Proceedings of the FAO /AADCP Regional Expert consultation on Farm- made Aquafeeds, 14 -18 December 1992, Bangkok, Thailand .FAO-RAPA /AADCP Bangkok, Thailand, pp. 434.

Yan X. and He Z. (1997). Study on the phytoplankton productivity in shrimp pond. J. Chin. Fish, 21(3): 288 - 295.

\section{ديناميكية الاكسجين الذائب اثناء الليل وآداء النمو للبلطي النيلي تحت احمال العليقة المختلفة \\ محمد احمد النادي - رشا خالا عبد الواحد ـ عبدالله عبد اللطيف عبد الجبار}

قسم الانتاج الحيو اني ـ كلية الزراعة - جامعة القاهرة

\section{ملخص المبام}

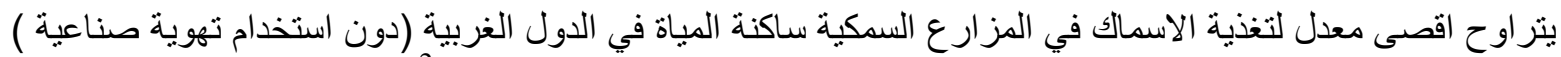

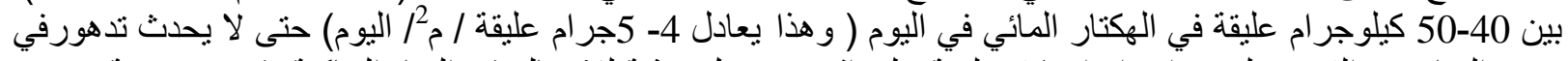

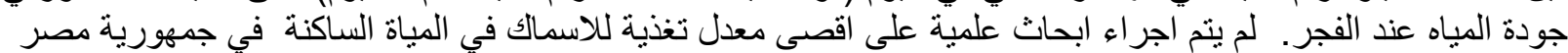

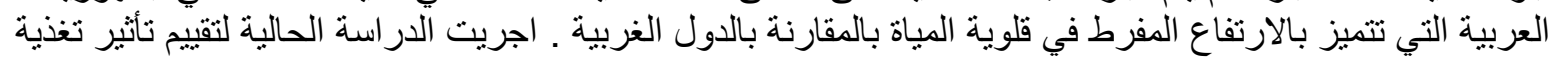

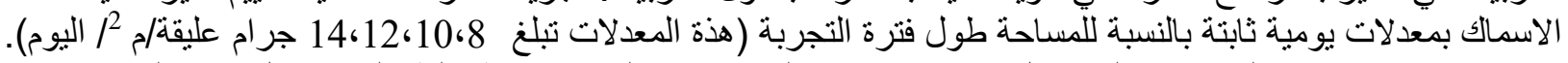

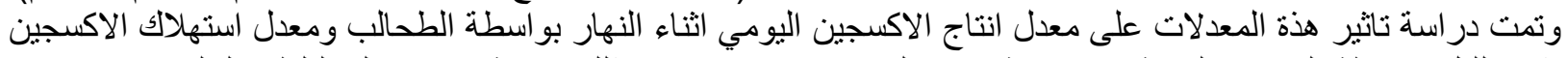

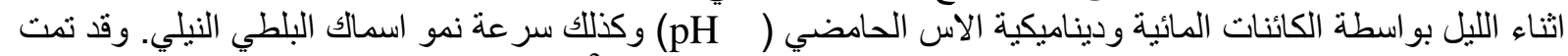

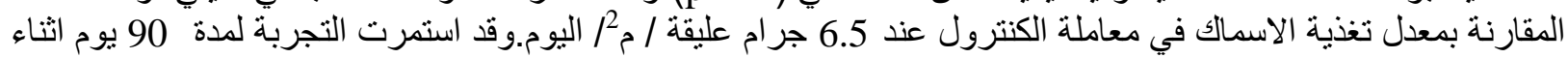

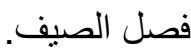

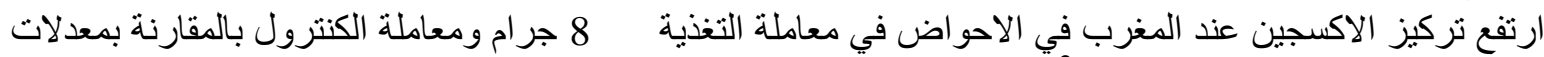

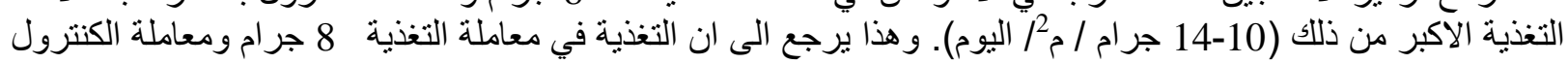

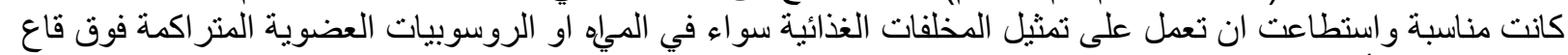

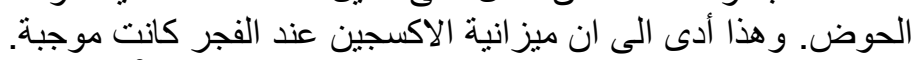

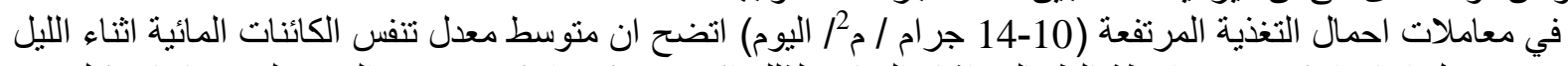

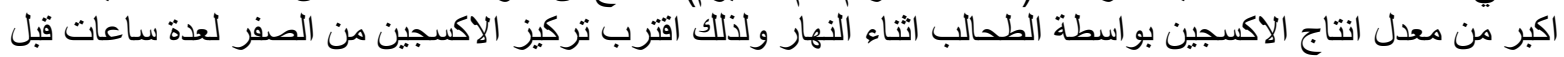

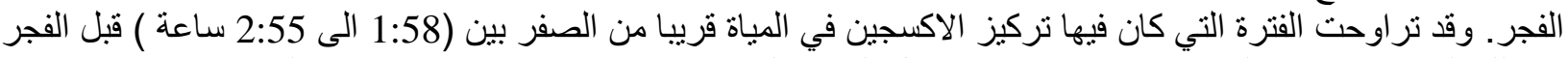

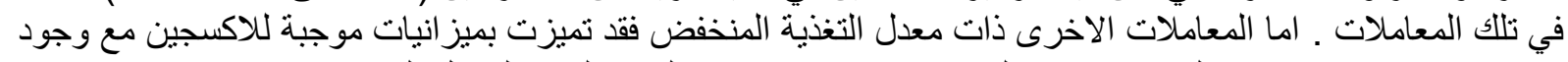

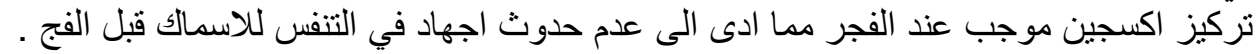

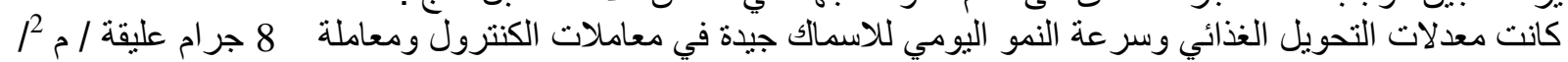

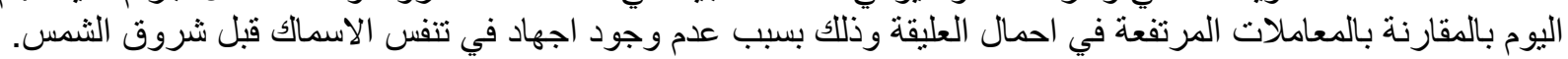

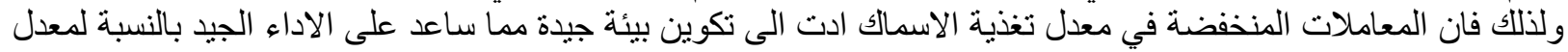

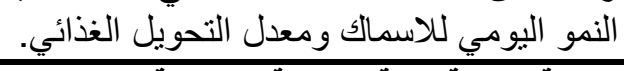

